\title{
Study on Growth and Yield of Sponge Gourd by using Plant Growth Promoting Rhizobacteria in Prayagraj Agro-climatic Condition
}

\author{
Gadha Sreekumar* and Devi Singh
}

Department of Horticulture, Naini School of Agriculture, Sam Higginbottom University of Agriculture, Technology and Sciences, Prayagraj 211007 (UP), India

*Corresponding author

\section{A B S T R A C T}

To study the effect of Plant Growth Promoting Rhizobacteria (PGPR) on growth and yield of Sponge Gourd; a field experiment was conducted on the research farm of the

\section{Keywords}

Azospirillum, Bacillus subtilis, Growth, PGPR, Sponge gourd, Yield

\section{Article Info}

\section{Accepted:}

26 July 2020

Available Online:

10 August 2020 Department of Horticulture, SHUATS, Prayagraj during 2019-20. Four PGPR strains, Azospirillum, Phosphorous Solubilizing Bacteria, Bacillus subtilis, and Pseudomonas fluorescens are studied and replicated thrice in a Randomized Block Design in $3 \times 2 \mathrm{~m}^{2}$ plot size. Early germination was observed in Azospirillum treatment followed by the Bacillus subtilis application recorded 4.07 and 4.14 days respectively. The study revealed that the maximum vine length $(6.32 \mathrm{~m})$ and $(6.25 \mathrm{~m})$ was reported in the double application of Bacillus subtilis (basal+30DAS) and double application of Pseudomonas fluorescens (basal+30DAS). Number of primary branches was maximum (5.87) in plants supplied with the double application of Bacillus subtilis as (basal+30DAS). Bacillus subtilis (basal+30DAS) were found to be the best treatment for the fruit length, girth, and weight with $25.05 \mathrm{~cm}, 4.84 \mathrm{~cm}$, and $131.83 \mathrm{gm}$ respectively followed by the single application of Bacillus subtilis with $24.61 \mathrm{~cm}, 4.71 \mathrm{~cm}, 123.91 \mathrm{gm}$ respectively. Application of Bacillus subtilis (basal+ 30DAS) produced the maximum yield/plant and yield/ha $(4.84 \mathrm{~kg}$ ) and (132.65q/ha) respectively. Among the different PGPR studied, double application of Bacillus subtilis (basal+30DAS) performed best for flower, fruit, growth, and yield characters. The results of the experiment revealed that PGPR has a wide range of beneficial effects on improving the growth and yield of Sponge gourd.

\section{Introduction}

Clean agriculture is vital for the future and it is supported by good agricultural practices as well as organic agriculture. The optimum use of resources in good agricultural practices minimizes the chemical inputs. Biofertilizers are low cost, renewable sources of plant nutrients and are gaining demand recently due to the increasing emphasis on conservation of soil health, minimize environmental pollution and to reduce the handling of the chemicals in agriculture. Biofertilizers have various benefits; by improving the soil health, fixing the soil properties, controlling soil borne diseases and increasing agricultural yield. Plant Growth Promoting Rhizobacteria (PGPR) was first defined by Kloepper and 
Schroth (1978) as a group of bacteria that actively colonize plant roots and increase plant growth and yield. The PGPR inoculants promote growth through suppression of plant disease (termed Bioprotectants), phytohormone production (termed Biostimulants) or improved nutrient acquisition (termed Biofertilizers).

In India, number of major and minor cucurbits is cultivated, which share about $5.6 \%$ of the total vegetable production (Rai et al, 2008). Through, authentic statistical records of area, production and productivity of Sponge gourd are not available, but in the year 2012 India ranked the second place in the production of Sponge gourd (FAO, 2010). The sponge Gourd (Luffa cylindrica Linn; $2 n$ 26) is one of the important tropical and subtropical cucurbitaceous crop grown extensively throughout India. It has a smooth surface and is one of the popular vegetable. It is a good source of vitamin A and C and has laxative properties. Fully ripen Sponge Gourds have high amount of fibers which are used as a cleansing agents [bathing and utensils] and making shoe soles, tablemates.

The sponge of the mature fruit helps the skin in increasing the blood circulation and as a relief for rheumatic and arthritis sufferers. Also the fruits are used to cure jaundice, diabetes, to purify blood and to cure skin diseases. However, such comprehensive studies on the influence of PGPR are at present lacking in sponge gourd.

PGPR as bio fertilizers are well recognized as efficient soil microbes for sustainable agriculture and hold great promise in the improvement of agricultural yields. As an option to all this use of bio-fertilizers can help us get back our soil health by natural way ultimately the health of organisms. Biofertilizer helped in plant growth, increase plant yield and provide the nitrogen to plant which is structural component for plant body therefore significantly contributes to plant growth (Khan et al., 2009).

Pseudomonas fluorescens is through four main mechanisms, viz., Competition, Antibiosis Mycoparasitism and Induced Systemic Resistance (ISR). Pseudo can also suppress diseases caused by foliar pathogens by triggering plant - mediated resistance mechanism called Induced Systemic Resistance (ISR) in plants against subsequent infection by fungal, bacterial and viral pathogens. Phosphate solubilising bacteria produce organic acids and enzymes that help in the solubilisation of insoluble phosphates into plant utilizable form. They also produce phytohormone like Indole acetic acid and gibberellins, which promote plant growth and yield. Azospirillum sp. is an associative nitrogen fixing bacteria that fixes atmospheric nitrogen in loose association with plant roots, for all plant species. Azospirillum sp. converts atmospheric nitrogen through the process of biological nitrogen fixation into ammonium which can be easily absorbed by the plant roots and provides $30-50 \%$ of plant nitrogen requirements.

In addition to this, Azospirillum sp. produces plant growth promoting substances like vitamins and phytohormone which influence plant growth especially root development to a large extent. Bacillus controls the growth of certain harmful bacteria and fungi by competing for nutrients, growth sites on plants and by directly colonizing and attaching to fungal pathogens. Seed treatment with Bacillus provides a protective zone around seeds. It also acts as a plant growth promoter. Since Bacillus is an aerobic spore forming bacteria, they remain viable on the leaf surface long after it has been sprayed. They also promote seed germination and early flowering \& fruiting. 


\section{Materials and Methods}

A field experiment entitled "Study on growth and yield of Sponge Gourd by using Plant Growth Promoting Rhizobacteria (PGPR) in Prayagraj agro-climatic condition" was conducted in the Department of Horticulture, SHUATS, Prayagraj during Kharif season 2019-20. The experiment was laid out in randomized block design (R.B.D.) with 3 replications of each treatment. Four PGPR strains are taken for the study viz., Azospirillum, Phosphorous solubilising bacteria (PSB), Bacillus subtilis, Pseudomonas fluorescens applied to Sponge Gourd variety Alok in 9 treatments as basal and basal +30 DAS. Sponge gourd seeds were planted in the field at a spacing of $1.5 \times$ $1 \mathrm{~m}$ in plots of $3 \times 2 \mathrm{~m}^{2}$ size. Standard cultural practices and plant protection measures were followed to raise a good quality crop. The mean values of each treatment in each replication for individual observation were calculated.

The experiment was conducted on sandy loam soil with $\mathrm{pH} 7.3$ and organic carbon $0.45 \%$ having available total nitrogen $0.84 \%$, phosphorous $0.64 \%$ and potassium $0.87 \%$. Observations on vegetative characters and yield attributes were recorded in each replication of all the treatments. The recommended manures and fertilizer doses were applied at the rate of 20 tonnes FYM and 40:40:30 kg N: P: K ha -1 respectively.

\section{Treatments}

T1-20t FYM \& 40:40:30 NPK kg/ha

T2-T1 + Azospirillum-5kg/ha (basal)

T3-T2 + Azospirillum-5kg/ha (30DAS)

T4-T1 + PSB - 5kg/ha (basal)

T5-T4 + PSB - 5kg/ha (30 DAS)

T6-T1 + Bacillus subtilis - 5kg/ha (basal)

$\mathrm{T} 7-\mathrm{T} 6+$ Bacillus subtilis $-5 \mathrm{~kg} / \mathrm{ha}$ (30 DAS)

T8-T1 + Pseudomonas fluorescens $-2.5 \mathrm{~kg} / \mathrm{ha}$ (basal)

T9-T8 + Pseudomonas fluorescens $-2.5 \mathrm{~kg} / \mathrm{ha}$ (30DAS)

\section{Results and Discussion}

The application of PGPR like Bacillus subtilis, Pseudomonas fluorescens Azospirillum and Phosphorous solubilising bacteria (PSB), showed significant and vital effect on growth and yield parameters of Sponge Gourd.

\section{Growth characters}

Analysis of variance showed that there was significant difference among the treatments for the characters vine length, number of lateral branches, germination, male flower and male flower. Days to germination was the earliest in Azospirillum treatment (T2) followed by Bacillus subtilis application (T6) which recorded 4.07 and 4.14 days respectively. Compared to other treatments Control (T1) took more days for germination (5.03days). The early germination could be due to the ability of Azospirillum to produce some growth promoting substances like auxins which might have led to enhance the physiological process in seeds, increased uptake of the nutrient and moisture (Kloepper, 2003). The colonization of this bacterium reduced the incidence of seed mycoflora which indirectly enhanced seed germination. Similar results have been obtained for Azospirillum on germination of watermelon and okra as reported by Nallathambi et al., (2003) and Prabhu et al., (2003) respectively.

The maximum vine length of sponge gourd was recorded in double application of Bacillus subtilis (T7) and double application with Pseudomonas fluorescens (T9) with $6.32 \mathrm{~m}$ and $6.25 \mathrm{~m}$. Control (T1) recorded the minimum vine length $(4.55 \mathrm{~m})$. The probable, reason for the increase in the biometrical 
characters of the crop may be a blend of volatile organic compounds (Kloepper, 2003). Kevin (2003) reported that some of the strains of Bacillus were found to produce mixtures of lactic acid, isovalaric acid, isobutaric acid and acetic acid which might have directly or indirectly promoted the growth attributes. This finding is in confirmation with the results of Lucas-Garcia et al., (2004) in tomato and pepper (Fig. 1 and Table 1).

The maximum Number of leaves per plant 90 DAS was found in the double application of Bacillus subtilis followed by double application of Pseudomonas fluorescens which recorded 55.83 and 54.17 respectively. The minimum numbers of leaves were recorded in control (43.26) and Azospirillum (46.04). The maximum Number of primary branches per plant was recorded in double application of Bacillus subtilis treatment (T7) followed by two time application of PSB (T5) which recorded 5.87 and 5.72 respectively. Control (T1) and Azospirillum (T2) recorded minimum number of primary branches (3.70 and 4.17). Anburani and Manivannan (2002) reported that there is an increase in number of secondary branches in brinjal by PSB application.

The character, days to first female flower was lowest in control (T1) followed by the treatment Azospirillum (T2) which recorded 40.79 days and 38.58 days respectively. Double application of Bacillus subtilis (T7) recorded the maximum days to appearance of first female flower 36.27 days followed by single application of Bacillus subtilis (T6) 36.44 days.

The character, days to first female flower was lowest in Azospirillum (T2) followed by the treatment control (T1) which recorded 38.94 days and 38.61 days respectively. Double application of Bacillus subtilis (T7) recorded the maximum days to appearance of first female flower 34.84 days followed by single application of Pseudomonas fluorescens (T9) 35.14 days.

\section{Yield characteristics}

Analysis of variance showed that there was significant difference among the treatments for the fruit characters, fruit yield per plant and fruit yield per plot. The maximum number of fruits was recorded in double application with Bacillus subtilis T7 (32.78) which were significantly superior over all other treatments followed by single application of Bacillus subtilis T6 (29.63). Similar results have been reported by LucasGarcia et al., (2014) who has reported that the tomato plants supplied with Bacillus lichemaformis recorded significantly increased number of fruits and diameter of fruits. Double application of Bacillus subtilis were found to be the best treatment for the fruit length, girth, and weight with $25.05 \mathrm{~cm}$, $4.84 \mathrm{~cm}$, and $131.83 \mathrm{gm}$ respectively followed by the single application of Bacillus subtilis with $24.61 \mathrm{~cm}, \quad 4.71 \mathrm{~cm}, \quad 123.91 \mathrm{gm}$ respectively. Mashooda-Begum (2013) also got similar results in okra, wherein Bacillus pumilus, Bacillus pasteurii, Bacillus subtilis and Bacillus subtilis strains significantly increased the total number of leaves, fruits, mean length, girth and biomass of fruits.

The maximum yield per plant was recorded in double application with Bacillus subtilis T7 (4.84) which were significantly superior over all other treatments followed by single application of Bacillus subtilis T6 (3.90).The results of this experiment are supported by the findings of Yobo et al., (2004), who recorded significantly higher fruit yield in pepper by application of Bacillus subtilis. This noticeable increase in yield might be due to the production of phytohormones such as zeatin, gibberelic acid and abscisic acid by Bacillus subtilis (Kilian et al., 2000) (Fig. 2 and Table 2). 
Table.1 Effect of different PGPR treatments on vegetative characters of sponge gourd

\begin{tabular}{|c|c|c|c|c|c|}
\hline Treatments & $\begin{array}{c}\text { Days to } \\
\text { Germination }\end{array}$ & $\begin{array}{c}\text { Vine } \\
\text { Length }\end{array}$ & $\begin{array}{c}\text { Number of } \\
\text { Primary } \\
\text { Branches }\end{array}$ & $\begin{array}{c}\text { First Male } \\
\text { Flower } \\
\text { Appearance }\end{array}$ & $\begin{array}{c}\text { First Female } \\
\text { Flower } \\
\text { Appearance }\end{array}$ \\
\hline T1 & 5.03 & 4.55 & 3.90 & 38.61 & 40.79 \\
\hline T2 & 4.07 & 5 & 4.17 & 38.94 & 38.58 \\
\hline T3 & 4.20 & 5.15 & 4.98 & 36.83 & 37.54 \\
\hline T4 & 4.60 & 5.5 & 5.50 & 36.65 & 38.47 \\
\hline T5 & 4.74 & 5.74 & 5.72 & 36.07 & 37.06 \\
\hline T6 & 4.14 & 6.18 & 5.27 & 35.27 & 36.44 \\
\hline T7 & 4.23 & 6.32 & 5.87 & 34.84 & 36.27 \\
\hline T8 & 4.34 & 5.92 & 5.02 & 35.86 & 36.68 \\
\hline T9 & 4.71 & 6.25 & 5.10 & 35.14 & 36.51 \\
\hline CD $(\mathbf{0 . 0 5})$ & $\mathbf{0 . 4 6}$ & $\mathbf{0 . 9 5}$ & $\mathbf{0 . 9 5}$ & $\mathbf{2 . 6 6}$ & $\mathbf{0 . 5 3}$ \\
\hline
\end{tabular}

Table.2 Effect of different PGPR treatments on yield of Sponge gourd

\begin{tabular}{|c|c|c|}
\hline Treatments & Yield per plant $\mathbf{( k g )}$ & Yield per ha $(\mathbf{Q})$ \\
\hline T1 & 2.79 & 98.53 \\
\hline T2 & 3.24 & 107.76 \\
\hline T3 & 3.31 & 114.90 \\
\hline T4 & 3.21 & 104.20 \\
\hline T5 & 3.40 & 118.91 \\
\hline T6 & 3.90 & 130.30 \\
\hline T7 & 4.84 & 132.65 \\
\hline T8 & 3.61 & 125.80 \\
\hline T9 & 3.74 & 127.84 \\
\hline CD $(\mathbf{0 . 0 5})$ & $\mathbf{0 . 3 3}$ & $\mathbf{0 . 9 7}$ \\
\hline
\end{tabular}

Fig.1 Effect of different PGPR treatments on days to germination, vine length and number of primary branches of Sponge gourd

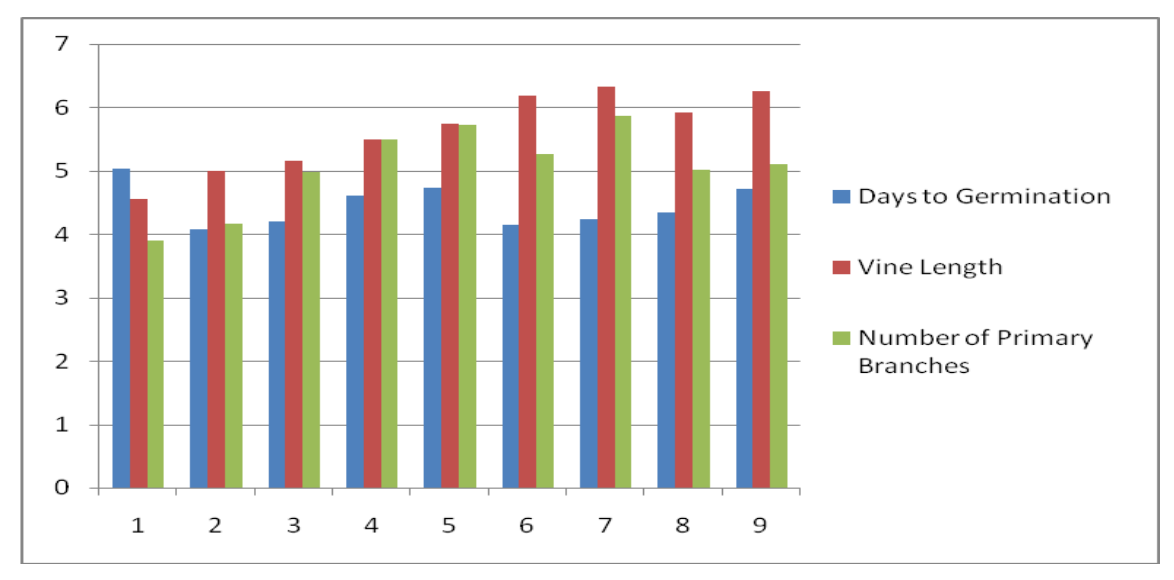


Fig.2 Effect of different pgpr treatments on yield/ha of Sponge gourd

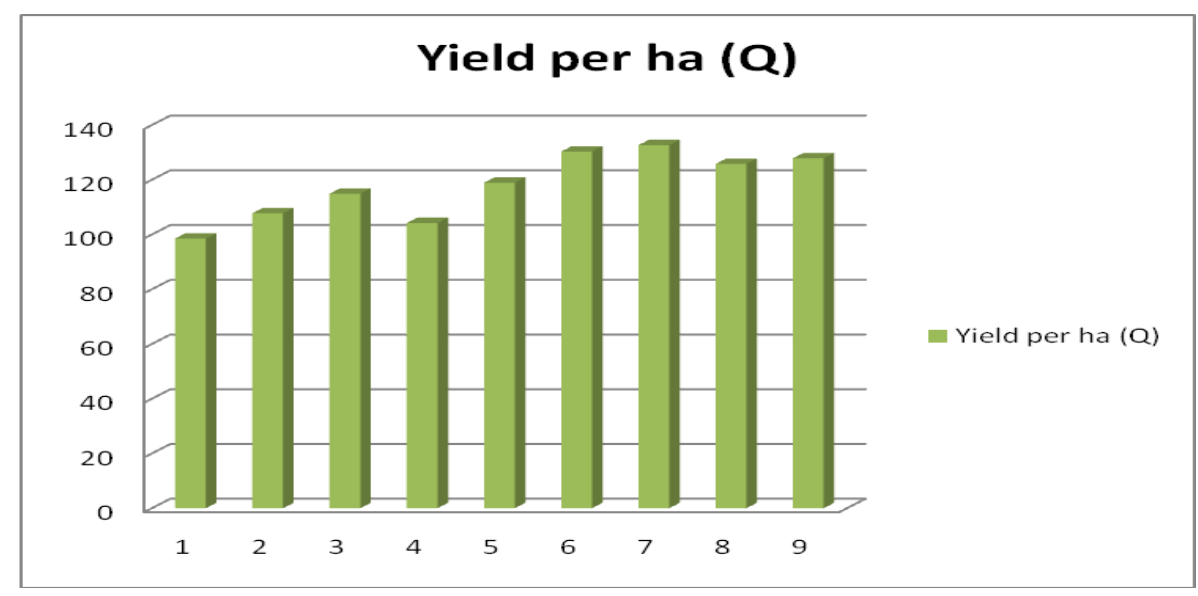

There was significant effect of application of PGPR on fruit yield per hectare. The maximum yield per plant was recorded in double application with Bacillus subtilis T7 (132.65) which were significantly superior over all other treatments followed by single application of Bacillus subtilis T6 (130.30). Woitke et al., (2004) also observed that Bacillus subtilis isolate increased yield of plants in addition to inducing resistance to biotrophic fungal plant pathogens. These are presumably transported into the shoot via the xylem. Intensified and prolonged synthesis of these phytohormones may be regarded as a cause of delayed senescence and improved yields (Kilian et al., 2000). The results of this experiment are supported by the findings of Yobo et al., (2004), who recorded significantly higher fruit yield in pepper by application of Bacillus subtilis.

In conclusion the Plant Growth Promoting Rhizobacteria (PGPR) rendered their significant effect on all the vegetative growth characteristics and yield attributing characteristics of Sponge Gourd cv. Alok combined with double application of Bacillus subtilis recorded maximum performance with respect to almost all the vegetative growth as well as yield characteristics. Control treatment, in which bio-fertilizers was not applied showed less performance out of all the treatments applied. Thus considering yield sustainability, ecosystem balance, soil health improvement and health of human beings use of plant growth promoting rhizobacteria is recommended for vegetable growers effectively.

\section{Acknowledgement}

My proud privilege to express a deep sense of gratitude to my advisor Dr. Devi Singh, Associate Professor, Department of Horticulture, Naini Agricultural Institute, SHUATS, whose generous help, untiring guidance, supervision, suggestions and positive attitude during my work. I express a deep sense of gratitude to all the teaching staff members of Department of Horticulture Dr. Vijay Bahadur, Dr. S. S. Saravanan, Prof. (Dr.) V. M. Prasad, Dr. Samir E. Topno, Mr. Deepanshu, Dr. Urfi Fatmi, Mr. Deepak Lall, and Dr. Anita Kerketta for their persistent help and valuable information's regarding the work.

\section{References}

Anburani A, Manivannan K. Effect of integrated nutrient management on growth in Brinjal (Abelmoschus esculentus). Indian Hort 2002; 50: 377-386. 
Kevin VJ. Plant growth promoting rhizobacteria as biofertilizer. Plant and Soil 2003; 255: 571-586.

Kloepper JW. A review of mechanisms for plant growth promoting by PGPR. Proceeding of 6th international plant growth promoting rhizobacetria (PGPR) workshop, 2003; 5-10 Oct. Calicut, India, 81-90.

Naidu AK, Kushwah SS, Dwivedi YC. Influence of organic manures, chemical and biofertilizers on growth, yield and economics of Brinjal. S Indian Hort 2002; 50: 370-376.

Nelson LM. Plant growth promoting rhizobacteria (PGPR): prospects for new inoculants. Crop Management. 2004; 4(1): 49-51.

Omar MNA, El-Kattan MH. Utilization of microbial inoculants for the enhancement of some vegetables yield under protected agriculture system. Acta Horticulturae 2003; 608: 57-65.

Tilak KVBR, Ranganayaki N, Manoharachari C. Contribution of plant growth promoting rhizobactria in crop production - Indian scenario. Proceeding of 6th international plant growth promoting rhizobacteria (PGPR) workshop, 2003; 5-10 Oct., Calicut, India, pp. 247-248.

Vessey, J. Kevin (2003). "Plant growth promoting rhizobacteria as biofertilizers". Plant and Soil.

Yobo KS, Laing MD, Hunter CH. Effect of commercially available rhizobacteria strains on rowth and production of lettuce, tomato and pepper. S African J Pl. Soil 2004; 21: 230-235.

http://nhb.gov.in/

\section{How to cite this article:}

Gadha Sreekumar and Devi Singh. 2020. Study on Growth and Yield of Sponge Gourd by using Plant Growth Promoting Rhizobacteria in Prayagraj Agro-climatic Condition. Int.J.Curr.Microbiol.App.Sci. 9(08): 3585-3591. doi: https://doi.org/10.20546/ijcmas.2020.908.413 